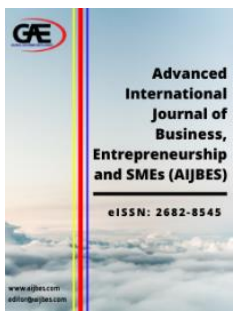

\author{
ADVANCED INTERNATIONAL JOURNAL OF \\ BUSINESS, ENTREPRENEURSHIP AND SMES \\ (AIJBES) \\ www.aijbes.com
}

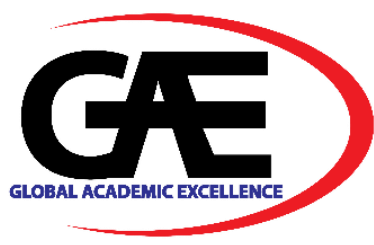

\title{
STUDY OF PAST DECADE (2010 - 2020) SELECTED LITERATURE ON MINORITY SHAREHOLDER AND SHAREHOLDER ACTIVISM IN MALAYSIA
}

Thiam-Yong, Kuek ${ }^{1}$, I-Chi, Chen ${ }^{2}$, Yuen-Onn, Choong ${ }^{3}$, Saw-Chin, Khor ${ }^{4}$, Mei-Peng, Low ${ }^{5}$, Timothy Tzen-Vun, Yap ${ }^{6}$

$1 \quad$ Faculty of Business and Finance, Universiti Tunku Abdul Rahman, Malaysia

Email: kuekty@utar.edu.my

2 Faculty of Business and Finance, Universiti Tunku Abdul Rahman, Malaysia

Email: chenic@utar.edu.my

$3 \quad$ Faculty of Business and Finance, Universiti Tunku Abdul Rahman, Malaysia

Email: choongyo@utar.edu.my

$4 \quad$ Faculty of Business and Finance, Universiti Tunku Abdul Rahman, Malaysia

Email: sckhor@utar.edu.my

$5 \quad$ Faculty of Accountancy and Management, Universiti Tunku Abdul Rahman, Malaysia

Email: lowmp@utar.edu.my

$6 \quad$ Faculty of Computing and Informatics, Multimedia University, Malaysia

Email: timothy@mmu.edu.my

\section{Article Info:}

\section{Article history:}

Received date:31.01.2021

Revised date: 09.02.2021

Accepted date: 14.02 .2021

Published date: 01.03.2021

To cite this document:

Kuek, T. Y., Chen, I. C., Choong, Y. O., Khor, S. C., Low, M. P., \& Yap, T. T. V. (2021). Study Of Past Decade (2010 - 2020) Selected Literature On Minority Shareholder And Shareholder Activism In Malaysia. Advanced International Journal of Business, Entrepreneurship and SMEs, 3 (7), 49-58.
Abstract:

Due to its vitality in preserving the stability, transparency, and sound management of businesses, corporate governance continues to play a dominant role in many Malaysian companies. This will give the country and foreign countries good opportunities to invest in Malaysia and provide an investmentfriendly environment. It adds color to the existing soft stock market in Malaysia as a result of the economic instability, the political turmoil, and the pandemic effects of Covid-19. Two main elements of corporate governance in Malaysia, minority shareholders, and shareholder activities will be addressed in this article. Minority shareholders, in particular publicly-listed companies in Malaysia, are major players in companies. However, in other countries, the general opinion among minority shareholders is that executives, administrators, and main shareholders or control shareholders tend to take advantage of them for their own personal purposes. As a result, shareholder activism plays a key role in making shareholders aware of their rights and obligations in the ownership of the firm, in particular as minority shareholders, through this activism. However, Malaysia has not yet come to a firm conclusion on the effectiveness of shareholder interference. Five articles on minority shareholders and shareholder activism relevant to Malaysia, each 
DOI: $10.35631 /$ AIJBES.37005.

This work is licensed under $\underline{\text { C B BY } 4.0}$ from 2010 to 2020, were retrieved from Google Scholar and examined from Malaysia's corporate governance perspective to determine the extent of their growth.

Keywords:

Corporate Governance, Minority Shareholder, Shareholder Activism, Malaysia

\section{Introduction}

National regional financial crisis, the scandalous collapse of well-established companies such as Dick Smith (Australia) and Wirecard AG (Germany) and recent financial scandals. Malaysia's 1MDB controversy involving the reputable Goldman Sachs has been a significant news item in the area of corporate governance research in recent years. According to Claessens and Yurtoglu (2012), such a crisis has not only made the governing system a familiar word, but has also brought to light the possible macro, distributive and long-term implications of weak corporate governance systems on the part of academics, companies and politicians from around the globe. In contrast, L'Huilier's (2014) literature analysis of the idea of corporate governance shows the benefit of agency theorists. The connotative sense of corporate governance is therefore fair to conclude that this is the principle of control expressed by the police procedures used to minimize losses of agencies. In short, corporate governance remains the key to improving the structural aspect of companies that do not easily fall apart because agents, such as directors or key or controlling owners, have unethical, unfaithful or illegal acts. In addition, the Agency's theory remains a matter of controversy on the expropriation of minority shareholders. La Porta, Lopez-de-Silanes and Shleifer (1999) have emphasized that this is a widespread issue in many nations apart from the United States, and De Cesari has agreed to do so (2012). For example, Hamid, Ting and Kweh (2016) expressed concern that agents in Malaysia will use tunneling and support at the expense of minority shareholders. At the same time, there are concerns about the lack of active shareholder activism in educating minority shareholders about their rights and encouraging institutional shareholders to take part as 'big brother' (Hamdani \& Yafeh, 2013). Although awareness on their rights has been increasing over the years, the lack of significant contribution as mentioned by Arrifn, WanHussin and Malak (2020) is disturbing. Afterall, minority shareholder investment protection was enhanced by increasing corporate governance (Kanthapanit \& Kanthapanit, 2020). Thus, we would like to research the relevant minority shareholders welfare and shareholder activism in Malaysia in order to assess the extent of their growth from Malaysia's corporate governance perspective by selecting five articles from Google Scholar each from 2010 to 2020. A content analysis methodology has been introduced to analyze important details of minority shareholders and shareholders' knowledge of activism. This paper is structured into two key sections, which are covered by the literature review of Malaysia's Minority Activists and Malaysia's Shareholder Activism defined prior to the 2010 to 2020 conclusion and discussion.

\section{Literature Review}

\section{Articles Review on Malaysia Minority Shareholders (2010 - 2020)}

Ramli (2010) examined the relationship between major shareholders and the dividend policies of Malaysian listed companies, claiming that company dividends could be used as a means of exploiting minority shareholders' wealth. The trial covers Bursa Malaysia, a publicly listed non-financial (PLC) corporation continuously listed for the period 2002-2006. This study is a very critical part of the trial. Malaysia offers an excellent environment for the study of the 
Volume 3 Issue 7 (March 2021) PP. 49-58

DOI 10.35631/AIJBES.37005

partnership, as the ownership structure of the company is centralised in nature. This study shows that there are serious disputes in the East Asian world between controlling shareholders and minority shareholders in the region. The study shows that major shareholders are affected by the Malaysian dividend scheme. However, the analysis did not show any evidence of minority shareholders expropriated by the dividend scheme. The ongoing reform of the CG in Malaysia can lead to the use of dividend policy as a tool for the CG, especially when traditional management instruments have been ineffective in their monitoring functions (Tam \& Tan, 2007).

Mustafa, Latif and Taliyang (2011) have researched that companies should partner with related parties because they give a wide range of returns to their companies. Transactions between related parties are also viewed as unfavourable to international shareholders. There is still talk in the mass media about the expropriation of the rights of minority shareholders, and the intention is therefore to empirically define the degree of expropriation and to recognise the consequences of the expropriation of minority shareholders in Malaysia. The study showed that transactions between similar parties may have an effect on the expropriation of minority shareholders. The results indicate that corporate performance would worsen for companies engaging in real expropriation, e.g. some types of related transactions such as asset purchases, asset sales, equity, corporate relationships, and other transactions involving cash payments to controller owners. The Securities Commissions and the Minority Shareholder Watch Group (MSWG) may have a role to play in monitoring transactions to protect the interests of minority shareholders.

Lieu, Alfan and Devi (2015) pointed out that the current corporate governance literature focuses on the conventional shareholder manager, which is the main form of the organisation concerned (Jensen \& Meckling, 1976). They studied whether the management of the concentration of shareholders influences the relationship between RTTs, which can lead to expropriation and value for money. RTPs leading to expropriation substantially lowered the business (Tobin Q and Market to Book Value (MBV) by 1\% and 5\% in both the normal pooled Ordinary Least Square (OLS) and the Firm Effect Model (FEM). The results of regression in ordinary pooled lower squares (OLS) and FEM suggest that RPTs likely to lead to expropriation are not closely linked to the fixed value of non-family firms. It shows that RPT expropriation by RTP minority shareholders is taking place among Malaysian businesses and that the reputational effects lead to a decline in the expropriation of minority shareholders by Malaysian family-owned companies. The Securities Commission in Malaysia (SCM), through RPTs, should concentrate its attention on the expropriation of minority shareholders, and SCM should review Section 8, paragraph. 8.1-8.3 to ensure that the interests of minority shareholders are covered by the Malaysian Code of Corporate Governance (MCCG).

In most countries, business managers have bad management practises, such as the personal use of corporate money. Minority shareholder rights in concentrated companies are primarily expropriated in Malaysia. The research of Umrani, Johl and Ibrahim (2015) focuses on the magnitude of the expropriation of minority rights, with an emphasis on the current Code of Ethics. In Malaysia, small and medium-sized enterprises make an immense contribution to the country's GDP and play a major role in the employment sector. Malaysia's Corporate Governance Code extends to classified public companies (MCCG). They are doing better than SMEs. They're doing better. Power of the family and centralised ownership of small and medium-sized Malaysian companies. Most shareholders are permitted to expropriate the rights of minority shareholders. You nominate family members and trusted friends to the board of 
Volume 3 Issue 7 (March 2021) PP. 49-58 DOI 10.35631/AIJBES.37005

directors. They are thus helped to expropriate the rights of shareholders. As a result, the Malaysian Government should take the requisite steps to resolve these problems in Malaysia's small and medium-sized enterprises. MCCG is the subject of publicly traded corporations. It was concluded that the Government of Malaysia would take the appropriate steps to address these problems in Malaysian small and medium-sized enterprises.

According to Ya'acob et al. (2018), the expropriation of shareholders' interest has been a global concern in recent decades. They discussed the important connection between corporate governance structures, namely the independence of the board and the independence of the audit committee, and the misuse of minority shareholder interest in relation to the activity of the related group in the ACE Market. An independent audit committee shall take accurate and equitable decisions on the grounds that they are independent and not closely linked to the company. While profit-making results in greater rentability, the rights of minority shareholders are more expropriated. Profitability illustrates the ability of the company to collect revenue over the year, but also reveals that profits can contribute to increased expropriation within the company. Previous research, however, suggest that profitability is adversely linked to the expropriation of minority shareholder interests (Berkman, Cole \& Fu, 2009; Nurul Huda, Rohaida \& Siti Mariana, 2011). However, you soon note that, when a higher value of productive companies can be expropriated, a positive correlation between profitability and expropriation can be expected.

\section{Article Reviews on Malaysia Shareholder Activism (2010 - 2020)}

Management interventions can be managed and supervised in a variety of ways to align management goals with shareholders, but the performance of such processes depends on a number of factors. The analysis by Azizan and Ameer (2012) shows no significant positive abnormal returns on the event day itself, but states that the post-event windows display significant positive cumulative abnormal returns (CARs), which show that shareholder activism has a delayed effect on shareholder capital. It was noted that the Minority Shareholders' Watch Group presented its letters on corporate governance concerning the independence of the Board of Directors (MSWG). This means that minority shareholders are very concerned about the legitimacy of the board, as the board is dominated by members of the family who are majority shareholders. Targeted family-controlled companies have related party transactions (RPTs). In the first part of their analysis, they examined whether the scale of the related sales and transactions of RPTs, i.e. changes from year to year as well as cross-sector sales, had shifted significantly with a matching example of the t-test process. The members of the audit committee engage in targeted firms significantly higher than non-targeted firms, even though the activities associated with such practise in Malaysia are lower than those seen in developed firms. The results show that the presence of MSWG shareholders has an effect on the return on the shareholding of family-controlled firms. These results indicate that familycontrolled businesses agree with the MSWG on topics that boost simple outcomes.

According to Musa (2012), shareholder activism is intended to resolve issues that emerge as a result of business agency problems. Institutional shareholders are usually private or public pension funds, insurance companies, banks, government entities and other institutional investment vehicles, such as charities. Controlled and structured bodies responsible for ensuring expected returns on their various investments, institutional shareholders allocate a certain amount of capital to control and monitor their investment portfolios. Such dedication and intervention should be minimal. Shareholder Activism is one of the best practises of the Malaysian Code of Corporate Governance. In the private sector, shareholder activism focuses 


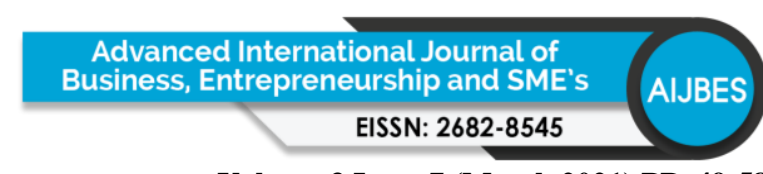

Volume 3 Issue 7 (March 2021) PP. 49-58

DOI 10.35631/AIJBES.37005

on institutional shareholders and government incentives for shareholder activism. Government agencies and family-owned companies are the major shareholders in the Malaysian stock market. Since the concentration of shareholders in Malaysia is high and the owners are managers, it does not seem appropriate to have a system that can reduce the costs and problems of the Agency. Research conducted between 434 companies listed in the Bursa Malaysia between 1999 and 2002 shows a significant and constructive relationship between institutional shareholders to corporate governance. In Malaysia, the institutional shareholders who use shareholder activism are typically government institutions and Malaysia's publicly listed companies as a whole have a better output in those government-owned companies. The Employee Provident Fund (EPF) is committed to fostering best practises in corporate governance among its investment firms through constructive dialogue and cooperation with the board and management of investment firms, as well as ongoing involvement in shareholders' meetings. Pemodalan Nasional Berhad (PNB) and Lembaga Angkatan Tentera Malaysia (LTAT) oversee and supervise their investment firms by board of directors; they also serve as insiders, playing an important role in performance management and even corporate governance. This advocacy would play an important role in minimising the costs of equity agencies by closely monitoring corporate governance practises through the provision of voting rights, the right to file suits and the sale of assets of managers and shareholders to ensure corporate sustainability and longevity. This dedication of shareholders affects the management of companies in a number of ways.

The paper written by Othman and Borges (2015) shows the scope of their participation and activism in the context of Malaysia. Strong shareholder engagement and responsible conduct are critical for effective market regulation and a culture of corporate governance. The principle of shareholder activism based on good corporate governance, and there is still controversy in this area in the corporate world. Shareholders at any point, ranging from institutional investors to single minorities and hedge funds, may observe shareholder activism in their strategic attempts to control firms (e.g., Fahmi \& Omar, 2005; Gantchev, 2013; Sikavica \& Tuschke, 2010). Shareholder advocacy in the United States, for example, has risen significantly since the introduction of a rule by the Securities and Exchange Commission (SEC), allowing shareholders to submit proposals that could be eligible for corporate voting in 1942. (Gillan \& Starks, 2007). Researchers have recently begun to recognise the importance of minority shareholder roles in advocacy and corporate governance as a whole in the sense of scholarly work in Malaysia (Abdul Wahab, How \& Verhoeven, 2007; Musa, 2012). The Malaysian Securities Committee and the Minority Shareholder Watch Group launched the Malaysian Code, the Malaysian Code for Institutional Investors, in 2014, following advocacy by Malaysian institutional shareholders with a list of best practises, jointly founded by Malaysia's largest institutional investors. Many of Malaysia's leading companies, such as the government, institutional shareholders and families, have little to no effect on management policy (Ameer \& Abdul Rahman, 2009). Guan (2005) claimed that minority individual shareholders are the largest group of shareholders and may be the most powerful.

Meanwhile, Akmal Musa and Ismail (2016) have added that shareholders are much more conscious of their investment obligations than in previous years. The involvement and commitment suggested by the best practises will allow companies to gain strength and improve their competitive edge in Malaysia. Institutional shareholders in Malaysia are primarily made up of Malaysian government departments and family businesses (Claessens, Djankov, Joseph \& Larry, 1999). Research conducted between 434 companies listed on the Bursa Malaysia from 1999 to 2002 found that the relationship between corporate governance and the interests of 


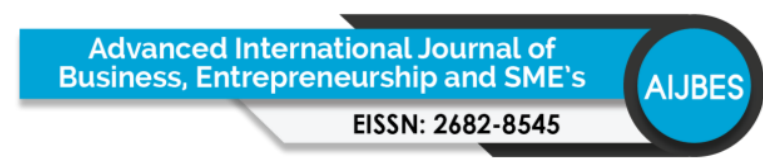

Volume 3 Issue 7 (March 2021) PP. 49-58 DOI 10.35631/AIJBES.37005

institutional shareholders is positive and significant (Abdul Wahab, How \& Verhoeven, 2008). A good positive relationship is clarified by a centralised shareholder control over the companies that will deter fraud and corporate scandal. The Board's efficiency, transparency, openness and disclosure, auditing and financial statements, internal control and risk management must be reviewed on a regular basis to ensure that governance is consistent with best practise. Hedge funds are said to be better placed to serve as smart monitors than other institutional investors, according to Latest Shareholder Activist, and their actions have been well viewed by the market (Thomas, 2008; Clifford, 2008). Research conducted between 434 companies listed on the Bursa Malaysia between 1999 and 2002 shows that institutional shareholder ownership has a deep, good relationship with corporate governance (Abdul Wahab, How \& Verhoeven, 2008). The interference of EPF to deter Golden Hope Bhd from selling a subsidiary to Iceland \& Peninsular Bhd. And the progress of the Fund in speeding up the privatisation of Malaysian Oxygen Bhd. EPF is committed to fostering the best practises of corporate governance among its investor companies through active interaction with and management of investment firms, as well as continuous participation in corporate shareholder meetings. In Malaysia, in general government agencies and Malaysia's publicly-listed companies as a whole, institutional shareholders who rely on shareholder activism show that better performance in those government-owned companies (Sulong \& Mat Nor, 2008), well-managed, open company makes shareholder involvement more than possible (Li, Moshirian, Pham \& Zein, 2004). It is very important to remember that programmes should not be invasive in terms of micromanagement of investor day-to-day operations.

Despite the existence of the shareholder rights regulatory system, arguments regarding shareholder activism remain controversial in a variety of respects (Goranova \& Ryan 2014). Othman, Ho and Latiff (2019) agreed that the approach of the individual minority shareholder and the agitation of the exit-loyalty-neglect model were linked to the unhappiness of the shareholders, pointed out the value and inadequacy of the management actions of the shareholders. Their research deals with the position of individual minority shareholders and aims to complement existing studies of shareholder activism dominated by studies of institutional investors. It aims to add a rich overview of the variety of activism responses available from the various minority shareholders to the shareholder activism literature. Researchers have attempted to improve their knowledge of the different approaches to advocacy adopted by individual minority shareholders in Malaysia's listed public companies. Where the size of the shareholding involved was minimal, as was the case for individual minority shareholders, the exit mechanism seemed to be less successful. Both shareholders must exercise their powers as the head of the company and must act and exercise their rights accordingly. Unfortunately, many minority shareholders appear to fail to realise that they can influence and change the behaviour of the organisations in which they participate, simply through an effective activist approach.

\section{Conclusion And Discussion}

Over the years, the study shows that positive improvements have taken place in Malaysia in the interests of minority shareholders and in the interests of shareholder activism. Minority shareholders tend to be in conflict with administrators or managers known as the Type I Agency Problem and major or controlling shareholders known as the Type II Agency Problem (Loderer \& Waelchli, 2010). However, the Type I problem tends to be reduced, especially in companies listed in Malaysia, while the Type II problem remains a constant concern for minority shareholders. One rational reason is possibly due to the requirement enforced by Bursa Malaysia that listed companies in Malaysia should apply the current Malaysian Code of Copyright $\odot$ GLOBAL ACADEMIC EXCELLENCE (M) SDN BHD - All rights reserved 


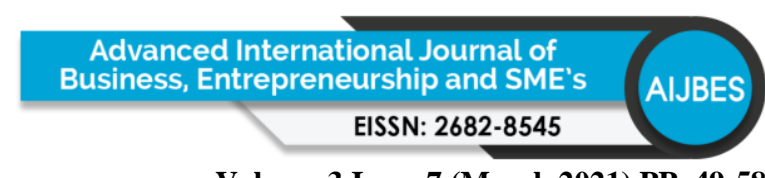

Volume 3 Issue 7 (March 2021) PP. 49-58

DOI 10.35631/AIJBES.37005

Corporate Governance (MCCG), which consists of practices that control the conduct of business agents. However, MCCG is not mandatory for unlisted firms. Moreover, the practices therein have little effect on restricting the actions of major or controlling shareholders, such as controlling shareholders who operate the company by setting their own remuneration, which would lead to the expropriation of minority shareholders in the company (Lim \& Yen, 2017). This is particularly evident in a family-controlled business. It is therefore suggested that the authority should consider making MCCG mandatory for all companies in Malaysia with a prescriptive approach compared to the current hybrid approach. The Authority should also consider more practices that could protect and prevent the expropriation of minority shareholders and limit the power of major or controlling shareholders in the future MCCG.

As far as shareholder advocacy is concerned, the Minority Shareholders Watch Group (MSWG) has done a good job of educating shareholders, in particular minority shareholders, on their rights and how they can contribute to the improvement of corporate governance by acting as their supervisory mechanisms. However, as a result of the report, institutional shareholders, on the one hand, need to play a more active role in this advocacy, it seems like they have not yet done enough. While it is understandable that institutions tend to be operating in dual roles as shareholders and investors (Afza \& Nazir, 2015), there must be a proper balance between the two roles for the benefit of its members as well as the shareholders of investment companies, in particular the minority Afterall, shareholder activism and minority shareholders. Institutional shareholders tend to be very involved in the company as they tend to have a lot of voting rights in the company. As a result, they can act as sound corporate governance in their investment companies where the collectivism of minority shareholders does not have an opportunity there. The Malaysian Institutional Investors Council also needs to update its Malaysian Code for Institutional Investors (MCII) as it has been six years since it was introduced without a revised edition. Changes in the atmosphere of corporate governance are nuanced. There is a persistent and continuing need for its activities to represent the right roles that institutional shareholders should play in their activism.

\section{Future Research}

According to Islam (2020), shareholder activism rises as corporate governance efficiency declines. Although we understand the rationale behind the increase in shareholder activism in this regard, there is a need for a thorough analysis of the mechanism for improving shareholder activism post poor corporate governance efficiency, probably with a longitudinal study in it. There is also a need to research the effect on institutional shareholder activism in Malaysia, as past studies in other countries, such as China, have shown that such activism can spread its wings to defend minority shareholders directly (by voting) and indirectly (by monitoring) (Huang \& Zhu, 2015; Lin \& Fu, 2017; Zhou \& Lan, 2018). It would be critical to note if the same phenomenon is taking place in Malaysia.

\section{References}

Abdul Wahab, E. A., How, J. C. Y., \& Verhoeven, P. (2007). The Impact of the Malaysian Code on Corporate Governance: Compliance, Institutional Investors and Stock Performance. Journal of Contemporary Accounting \& Economics, 3(2), 106-129. doi:10.1016/S1815-5669(10)70025-4

Abdul Wahab, E. A., How, J. \& Verhoeven, P. (2008). 'Corporate Governance and Institutional Investors: Evidence From Malaysia.' Asian Academy of Management of Accounting and Finance, 4:2, 64-90. 
Volume 3 Issue 7 (March 2021) PP. 49-58 DOI 10.35631/AIJBES.37005

Afza, T., \& Nazir, M. S. (2015). Role of institutional shareholders' activism in enhancing firm performance: The case of Pakistan. Global Business Review, 16(4), 557-570.

Akmal Musa, M., \& Ismail, S. E. (2016). Shareholder Activism, Institutional Shareholders and Agency Problems in Malaysia. Global Journal of Business and Social Science Review, 4(3), 30-36.

Ameer, R., \& Abdul Rahman, R. (2009). The Impact Of Minority Shareholder Watchdog Group Activism On The Performance Of Targeted Firms In Malaysia. Asian Academy of Management Journal of Accounting and Finance, 5(1), 67-92.

Ariffn, M. S. M., Wan-Hussin, W. N., \& Malak, S. S. D. (2020). A. Level of Shareholders Activism among Malaysian listed companies-An overview. Journal of Advanced Research in Business and Management Studies, 19(1), 60-72.

Azizan, S. S., \& Ameer, R. (2012). Shareholder activism in family-controlled firms in Malaysia. Managerial Auditing Journal. Vol. 27 Issue: 8, pp.774-794.

Barbara Marie L'Huillier, (2014) "What does "corporate governance" actually mean?", Corporate Governance, Vol. 14 Issue:3, pp.300-319.

Berkman, H., Cole, R. A., \& Fu, L. J. (2009). Expropriation through loan guarantees to related parties: Evidence from China. Journal of Banking \& Finance, 33(1), 141-156.

Claessens, S., Djankov, S., Joseph, F. \& Larry, L. (1999). 'The expropriation of minority shareholders: Evidence from East Asia.' Washington, DC.: World Bank.

Claessens, S., \& Yurtoglu, B. B. (2013). Corporate governance in emerging markets: A survey. Emerging markets review, 15, 1-33.

Clifford, C. P. (2008). 'Value creation or destruction? Hedge funds as shareholder activists.' Journal of Corporate Finance, 14 1, 323-36.

De Cesari, A. (2012). Expropriation of minority shareholders and payout policy. The British Accounting Review, 44(4), 207-220.

Fahmi, F. M., \& Omar, N. (2005). Corporate Reporting on Minority Shareholders Information and Its Implication on Shareholders Activism in Malaysia. Journal of Financial Reporting and Accounting, 3(1), 17-39.

Gantchev, N. (2013). The costs of shareholder activism: Evidence from a sequential decision model. Journal of Financial Economics, 107(3), 610-631. doi:10.1016/j.jfineco.2012.09.007

Gillan, S. L., \& Starks, L. T. (2007). The Evolution of Shareholder Activism in the United States. Journal of Applied Corporate Finance, 19(1), 55-73. doi:10.1111/j.17456622.2007.00125.x

Goranova, M., \& Ryan, L. V. (2014). Shareholder activism: A multidisciplinary review. Journal of Management, 40(5), 1230-1268.

Guan, C. (2005). Corporate governance reforms in Malaysia issues and challenges. In K. L. Ho (Ed.), Reforming Corporate Governance in Southeast Asia. Singapore: Institute of Southeast Asian Studies

Hamdani, A., \& Yafeh, Y. (2013). Institutional investors as minority shareholders. Review of Finance, 17(2), 691-725.

Hamid, M. A., Ting, I. W. K., \& Kweh, Q. L. (2016). The relationship between corporate governance and expropriation of minority shareholders' interests. Procedia Economics and Finance, 35, 99-106.

Huang, W., \& Zhu, T. (2015). Foreign institutional investors and corporate governance in emerging markets: Evidence of a split-share structure reform in China. Journal of Corporate Finance, 32, 312-326. 
Volume 3 Issue 7 (March 2021) PP. 49-58 DOI 10.35631/AIJBES.37005

Islam, A. U. (2020). Do Shareholder Activism Effect Corporate Governance and Related Party Transactions: Evidences from India?. Indian Journal of Corporate Governance, 13(2), 165-189.

Jensen, M. C., \& Meckling, W. H. (1976). Theory of the Firm: Managerial Be-havior. Agency Costs and Ownership Structure, 3J Fin Econ305, 311.

Kanthapanit, C., Kanthapanit, C. (2020). Protection of Minority Shareholder Investment in the Small and Medium-sized Enterprises. The Journal of Asian Finance, Economics and Business (JAFEB), 7(8), 451-459.

La Porta, Rafael, Florencio Lopez-de-Silanes, \& Andrei Shleifer (1999). Corporate ownership around the world. Journal of Finance 54, 471-517.

Li, D., Moshirian, F., Pham, P. K., \& Zein, J. (2006). When financial institutions are large shareholders: The role of macro corporate governance environments. The Journal of Finance, 61(6), 2975-3007.

Lim, B. L., \& Yen, S. H. (2017). Agency problem and expropriation of minority shareholders. Malaysian Journal of Economic Studies, 48(1), 37-59.

Lin, Y. R., \& Fu, X. M. (2017). Does institutional ownership influence firm performance? Evidence from China. International Review of Economics \& Finance, 49, 17-57.

Loderer, C., \& Waelchli, U. (2010). Protecting minority shareholders: Listed versus unlisted firms. Financial Management, 39(1), 33-57.

Yoong, L. C., Alfan, E., \& Devi, S. S. (2015). Family firms, expropriation and firm value: Evidence from related party transactions in Malaysia. The Journal of Developing Areas, 49(5), 139-152.

Musa, M. (2012). The influence of institutional shareholder activism as a corporate governance monitoring mechanism in Malaysia. Waset. org, 71, 1328-1332.

Mustafa, N. H., Latif, R. A., \& Taliyang, S. M. (2011). Expropriation of minority shareholders' rights: Evidence from Malaysia. International Journal of Business and Social Science, 2(13).

Nurul Huda, M., Rohaida, A. L. and Siti Mariana, T. (2011). Expropriation of minority shareholders' rights: Evidence from Malaysia. International Journal of Business and Social Science, 2(13).

Othman, S., \& Borges, W. G. (2015). Shareholder activism in Malaysia: Is it effective. Procedia-Social and Behavioral Sciences, 172, 427-434.

Othman, S., Ho, J. A., \& Latiff, A. R. A. (2019). Individual Minority Shareholder Activism Approaches and the Exit-Voice-Loyalty-Neglect Model. International Journal of Business and Society, 20(2), 823-839.

Ramli, N. M. (2010). Ownership structure and dividend policy: Evidence from Malaysian companies. International Review of Business Research Papers, 6(1), 170-180.

Sikavica, K., \& Tuschke, A. (2012). When Do Small Shareholders Take Action Against' Their 'Firm?: A Social Identity Approach to Small Shareholder Activism, 1-37. doi:http://dx.doi.org/10.2139/ssrn.2180039

Sulong, Z., \& Nor, F. M. (2008). Dividends, Ownership Structure and Board Governance On Firm Value: Empirical Evidences From Malaysian Listed Firm. Management \& Accounting Review (MAR), 7(2), 55-94.

Tam, On Kit and Monica Guo-Sze Tan. (2007). "Ownership, Governance and Firm Performance in Malaysia." Corporate Governance 15(2):208-222.

Thomas, R. S. (2008). The evolving role of institutional investors in corporate governance and corporate litigation. Vand. L. Rev., 61, 299. 
Volume 3 Issue 7 (March 2021) PP. 49-58

DOI 10.35631/AIJBES.37005

Umrani, A. I., Johl, S. K., \& Ibrahim, M. Y. (2015). Corporate Governance Practices and Problems Faced By SMEs in Malaysia. Global Business \& Management Research, 7(2).

Ya'acob, N. S., Faril, A. M., Dias, D. G., Jamaludin, N. I. A., Idrus, N. A. M., \& Salwi, N. N. C. M. (2018). The Determinants of Expropriation Minority Shareholders' Interest from Malaysian Ace Market. Global Business \& Management Research, 10(3).

Zhou, J., \& Lan, W. (2018). Investor protection and cross-border acquisitions by Chinese listed firms: The moderating role of institutional shareholders. International Review of Economics \& Finance, 56, 438-450. 